\title{
Saudi Arabian Women in Socio-Political Movements 2007 - 2017
}

\author{
Angga Laksana Tubagus ${ }^{1}$, Muhammad Lutfhi², Muhamad Syauqillah ${ }^{3}$, and \\ Mulawarman Hannase ${ }^{4}$ \\ \{ ${ }^{1}$ anggalaksanatubagus@gmail.com, ${ }^{2}$ m.luthfiz009@gmail.com, ${ }^{3}$ muhamadsyauqillah@ui.ac.id, \\ ${ }^{4}$ mhannase@yahoo.com\} \\ ${ }^{1,2,3,4}$ School of Strategic and Global Studies, Universitas Indonesia, Indonesia
}

\begin{abstract}
Saudi Arabia's government policy on the sex segregation between women and men encourages social unrest in Saudi Arabia, especially for women who are very limited in their social life. This study describes the socio-political conditions of women in Saudi Arabia and the socio-political movements of Saudi Arabian women in 2007 - 2017. This study uses a qualitative approach. The method used is the descriptive analytical method. The theory used in this study is a new social movement theory. According to Singh, the new social movement was a form of political resistance from the ordinary people who formed an alliance against the government authorities. The results showed that the social conditions of Saudi Arabian women were affected by several internal and regional political factors. The Saudi Arabian women's socio-political movement in 2007 - 2017 only struggled on campaigns on the social media and only a few took the form of demonstrations. The socio-political movement focused on lifting the ban on driving for women and revoking the trusteeship system for Saudi Arabian women.
\end{abstract}

Keywords: Saudi Arabian Women, Social Movements, Human Rights

\section{INTRODUCTION}

Saudi Arabia is a country with an absolute monarchy government system located on the Arabian Peninsula led by the Al Saud family, a family that has a close relationship with Wahabbi (Etheredge, 2011: 26). The population is estimated to reach 28.5 million people including 5.8 million people are the foreign residents. Most monarchies, such as Morocco, Jordan, Qatar, already have the transition system of power and conducted transparently. Unlike those, Saudi Arabia has transferred its power illegally, and not transparent that not only the outsiders of Saudi Arabia realize it, even the Saudi citizens themselves.

Women and men in Saudi Arabia do not have the same rights in education. Women, even though they have higher education and experience do not have the same rights in terms of employment. They cannot get a promotion. Women shall not be allowed to open the bank accounts without permission from their husbands or guardians. Women shall not be allowed to 
buy vehicle or property. Saudi Arabian women do not have the right to go to the police or court to file complaints without their male guardian. Because of the trusteeship system, women's health rights are threatened. They are not allowed to attend the hospital without their male guardian. Women in Saudi Arabia do not have child custody when they come to divorce from their husbands.

Discrimination against women in Saudi Arabia encourages a woman named Wajeha alHuwaider to make changes to women's human rights. Wajeha al-Huwaider is a Saudi Arabian women's rights activist and she is a writer too. Al-Huwaider once wrote for Al-Watan media in Arabic and English. She was ever banned from writing in 2003. She is also a member of the Middle East women's rights watchdog. Al-Huwaider was detained in 2006 for protesting in public asking for women's rights in King Abdullah's annual anniversary. She was also involved in a driving campaign for women in 2008. She was also arrested for trying to cross the Bahrain border without his male guardian in 2009 as a form of protest for the request for freedom to travel alone.

Several issues concerning the discrimination against women in Saudi Arabia encourages the author to explore more about the social conditions of women in Saudi Arabia in 2007 2017 and the socio-political movements carried out by Saudi Arabian women in 2007 - 2017. The method used in writing this article is a qualitative research method with descriptive analysis techniques. Data obtained from the literature reviews, journals, articles, theses and media both printed and online.

The theory of new social movements used as a theoretical basis in writing this article. The theory of new social movements considered as a reflection of the contemporary individual cultural rebellions that oppose the increasing mechanism of the state control and supervision system towards the society (Singh, 2010: 121-124). This control and supervision system by the state against the society occurs in Saudi Arabia. The government or in this case the king has complete control over the rules. The community is required to obey the rule by ignoring the values of human rights, especially Saudi Arabian women's rights. Some characteristics of the new social movements expressed by Singh have similarities with the movements that emerge in Saudi Arabia.

The characteristics of the new social movements include the narrowing of social space. For Saudi Arabian women, education, employment and travelling are impossible for them to be performed privately. The women must get a permission from their guardians or be accompanied by their guardians. The next characteristic of the new social movements is voicing, directing, and struggling for humanitarian issues and issues related to the fundamental conditions of human existence and the possible future worthiness. The new social movements tend to ignore the industrial trade union organization model and the party political models. New social movements generally involve grassroot politics, grassroot actions. It is often initiating the movement of micro-groups of small groups, targeting the local issues on a limited basis institution. They gave birth to a horizontally organized democratic association, 'which was established in a loose federation at national level' (Jean Cohen, 1985: 667) in Singh (2010: 128). The aim of the new social movements is to reorganize the relations of the state, society and the economy and to create a public space in which the democratic discourse regarding the autonomy and individual freedom and collectivity as well as their identity and orientation that can be discussed and always be examined. The structure of new social movements is defined by the plurality of ideals, goals, will and orientation and by the heterogeneity of their social base. Furthermore, the nature of new social movements expressed is not only in the term of socio-political and socio-cultural movements but also issues related 
to patriarchy, gender, country, culture, language and identity are the commitment of new social movements.

Concerning literature review of this research, Meilia Irawan, a student of the post-graduate program in the Middle Eastern and Islamic Studies, University of Indonesia has discussed on the Saudi Arabian women in 2014 under the title of Transformation of the Government of Saudi Arabia's Policy Since 2005: The Contribution of Women in the Social and Political Sphere. The research conducted by Mei focused on the Arabian government's policies on women's human rights in Saudi Arabia such as: prohibition of self-driving for women, limited access to work, absence of women's role in politics, and minimal social interaction. This research described more about the policy reforms carried out by the Saudi Arabia's political elite since 2005 as a form of modernization response in the country. However, Mei concluded that the transformation of Saudi Arabia's government policy towards women had to be attributed into the two important things. First, Saudi Arabia wants to be involved in the global economy so there is a need in the policy changes; second, this policy transformation was encouraged to keep the Saudi family's position at the top of Saudi Arabia's government. This study used the qualitative-explanatory research method by using the social change theory.

Research on women and the people of Saudi Arabia was also conducted by Yahya Alhareth, Yasra Al-hateth, and Ibtisam Al-Dighrir, 2015, entitled "Review of Women and Society in Saudi Arabia". The research with a qualitative approach found that the Saudi society is a unique blend of religion and culture, which creates difficulties for the government to carry out the education for women. The position of women in the world is determined by the authority all the time. This paper reviews the literature on women and society in Saudi Arabia and their relationship to their educational achievements, looking at several different aspects including: feminist theory, Islamic feminism in Saudi's society, status of women in Saudi society and the Muslim holy book (Al-Qur'an) and also comparison of the both.

\section{GENDER SEGREGATION POLICY AND THE EMERGENCE OF THE WOMEN'S MOVEMENT}

King Abdullah's policy of government regarding the socio-political status of women in Saudi Arabia in principle is almost the same as that of its predecessor, in which the empire is considered appropriate to advocate and impose the sex segregation as a whole. Although the policy does not discriminate when viewed from the basic legal values, this due to the regulation that is intended for both men and women. However, the policy in the reality is considered to prevent the Saudi Arabian women from practicing the significant public life.

The government policy in terms of sex segregation between women and men made Saudi Arabia face complex circumstances. Not only the intention to keep the Shari'a tradition, the policy actually clarifies the gap between women and men. The groups of people who wanted to experience the fruits of social and economic progress had to confront with safeguarding the values of tradition and government policy. This is so felt for women in Saudi Arabia who have very limited access. Furthermore, the royal government introduced a commission (run by the religious police) that is fully responsible for "promotion of virtue and prevention to vice" to closely monitor and implement the sex segregation in all workplaces outside the hospital, and several other places. In addition, the religious police given a full-strength mandate to arrest those who violate the state laws and regulations. This is in the contrary to Article 8 of the Basic Governance Act which states that "The system of the Kingdom of Saudi Arabia is based on justice, consultation and equality according to the Islamic Sharia (Islamic law)." In other 
words, there are contradictions between the basic laws that promote gender equality in all the articles and what actually happened in the real life (Rajkhan \& Dana, 2014).

The simple thinking about women in Saudi Arabia rises into two stereotypical images in mind. The first thought is that women are clad in black abaya (veil) which is often negatively connoted in terms of modernization. The second thought is rich women who enjoy the luxury of oil wealth. The oil boom in the 1970s presented a variety of blessings for Saudi women. The wealth surplus allows an increase in education and welfare and services for women. On the other hand, the wealth surplus has increased the process of marginalization, considering the state has implemented gender segregation for schools, hospitals and social services. In other words, oil wealth has made both the sticks and carrots for the Saudi Arabian women which means that the Saudi women individually benefit from a variety of modern facilities, but on the other hand slow down their emancipation process from the patriarchal policies (Sanauddin, 2013: 1).

Socially, in Saudi Arabia, there are various groups of women, ranging from the religious fundamentalist women's groups, to young women classified as the cosmopolitan sexneovelists. The liberal feminists and liberal Islamists are both active in negotiating the bargaining position with the state for women's rights in Saudi Arabia. But both groups of women's movements have fundamental differences regarding the causes of their suffering. Liberals see that women's suffering is the result of strict interpretation of Islam. Some of the opinions of the women's movement criticized the Wahhabi sect, which attacked the customs in old tribes in Saudi Arabia; but almost none of these schools criticized or attacked the country. However, both groups of women's movements have the view that the king is a savior, as a kind of "father" to save women from exploitation by the elements of society (Sanauddin, 2013: 2).

The social role of women in Saudi Arabia is determined by the interpretation of Islamic teachings and of the Sunni Islam. Most Islamic law comes from the Qur'an. There are many ways to interpret the Qur'an, however, the government of Saudi Arabia mostly follows what is stated in the Qur'an. Saudi Arabia is a country that follows most of the Islamic rules when compared to other Islamic countries. Saudi Arabia is a country that is considered to be the strongest in maintaining its local culture (Quila et al., 2016).

During the Iranian Revolution, the religious fundamentalists in Saudi Arabia demanded that Saudi Arabia had become a more conservative Islamic state. Among them is the termination of women's education. In addition, it is mandatory for women to use abaya in public. In addition, Saudi Arabia is known as the only country in the world that prohibits women from driving cars. Indeed, there is no prohibition in writing, but driving licenses) are only given to men. The religious authority, Al-Muttawah, announced that women driving are haram (forbidden) (Quila et al., 2016).

Since the activists fighting for women's rights were banned and arrested in Saudi Arabia, some women began moving and establishing the informal groups, and these women are judged to have committed crimes. For example, in 1990 dozens of women driving cars in Riyad were detained by the religious police. Their passports were confiscated, even though they were returned a year later. In 2007, a female activist named Wajeha al-Huwaider managed to collect thousands of women's signatures as a petition sent to King Abdullah. The petition demanded the rights that women are allowed to drive. The following year, Wajeha uploaded a video on YouTube depicting she was driving a car on the International Women's Day. This is part of the campaign to fight for the women's rights to be allowed to drive. In 2011, when the Arab Spring exploded many activists used the social media to start the movement including Manal al-Sharif. Manal made a video containing herself driving a car without a veil. The video was 
watched 700,000 times a day. From that moment on, Manal began receiving threats to be killed and raped unless she stopped campaigning for the freedom of driving. At that time, Manal was arrested and imprisoned. She was released by the police but by making an agreement not to drive a car anymore. In 2014, women drivers were treated like terrorists. Two Arabian women were detained and tried in a terrorist court, for violations of driving a car (Quila et al., 2016).

\section{SAUDI ARABIAN WOMEN'S POLITICAL CONDITION}

The Saudi Arabia is known as one of the most conservative monarchies in the world. Politically, this country is considered to be very authoritarian in the view of no constitution or legislation used in the power succession. The king ruled in full without control from the political parties. All the workers' associations, workers' strikes and workers' involvement in the collective bargaining are prohibited. Saudi Arabia is considered a country that does not put the basic freedoms needed for the formation of civil society. In 2002, the Freedom House labeled Saudi Arabia as one of the repressive regimes in the world. In terms of political and civil rights, Saudi Arabia ranked 1.0 in 2004 and 1.02 in 2014 (1 reflects the lowest score). Changes in the political conditions continuesly occur, but the changes are relatively slow (Fyfe, 2013). The World Economic Forum places Saudi Arabia at 141th place out of 144 countries in the Global Gender Gap Index. The Global Gender Gap Index released by the World Economic Forum in October 2016 showed zero for the category of women's political empowerment in Saudi Arabia (www.weforum.org/reports).

Historically, the Gulf countries including Saudi Arabia, have tended to maintain a patriarchal system, and the norms of local people living there who judge women as the second-class citizen. When Islam was introduced to the people of Saudi Arabia, observers considered that the roles of men and women were further strengthened in a patriarchal family system.

Today, an impartial policy is expected to emerge for Saudi Arabian women in political and civic life. This will manifest many of the hidden talents of women, which can increase the domestic economic activity, empower competition, reduce unnecessary costs of social segregation, enrich the cultural and social development, and help to encourage democratic institutions, thus, weakening the extremist influence in this country. With Saudi Arabia's significant regional and global religious and economic influence, women's empowerment in Saudi Arabia will radically increase opportunities for democratic reform. Empowering women is a moral imperative and a strong path to promoting the progress, tolerance and equality in society and the benefits they will add to the overall development in this country (Rajkhan \& Dana, 2014).

The religious anthropologist from King's College, University of London, Professor Madawi Al-Rasheed through his book entitled Gender, Politics, and Religion in Saudi Arabia revealed that the Saudi Arabian women's socio-political position is not purely to adhere Islam in general, but is a "tacit partnership" between the As-Saud family in power with the Wahabbiyya ideology (a strict Islamic version). The partnership, according to Al-Rasheed, has manipulated the image of women for religious and political interests. In the process of creating the Saudi nation, it was based on a godly Islamic nationalist identity. This is a structural marker boundary between the political groups of pious Muslim women and other women's political groups. The partnership succeeded in changing the socio-political orientation of Saudi Arabian women who Wahabiyya, from what was originally a "religious revivalist movement" 
to a religious nationalist movement "in an effort to unite the different ethnic groups into a godly nation.

Similar to most national movements, Saudi Arabia's religious nationalism uses women to unite in the symbol of a black abaya, and later. The symbol of this black abaya continues until now as a symbol of the women of Saudi Arabia. This was clearly seen from the uniform of female students in Saudi Arabia as well as in the Mitawween education (religious police working on doctrine). By placing the public education institutions and police education under the guidance of scholars, the state tries to generate the obedient, pious and devout women in an Islamic manner in accordance with their nature (Sanauddin, 2013: 1).

Meanwhile, Professor Michael Ross through the results of his study entitled "Oil, Islam and Women" argues that there is an inverse relationship between the social opportunities and the oil and women policy. Bad records in the Middle East about women's rights and equality, according to him, not because of the Islamic cultural heritage, but more because of the oil. Ross concluded the idea that "development leads to equality" does not apply in all cases, but depends on the type of development. Development that depends on oil and mineral income is possible for the preservation of patriarchal norms, laws and institutions in society. His study showed that the similar impact of oil to the status of women in the oil-rich countries were also applied outside the Middle East in some places such as Nigeria, Russia and Chile. Ross's research included the statistical data showing the relationship between the oil and its impact on women's work patterns and their opportunities for political representation. The data showed that the emergence of Saudi Arabia oil industry directly results in a decrease in the proportion of women in the workforce and the decision-making authority, a clear characteristic of Gulf society (Ross, 2008).

Before the oil era, women were an important part of the agricultural production and trade. They were not socially isolated in the usual way we see now. Moreover, in several regions in Saudi Arabia, women's face covering was not unusual until after 1980 - after the Islamic revolution in Iran and the occurrence of the uprising at the Grand Mosque in Mecca which caused the increased of conservatism. There is no doubt that this lead to the reducing of women's employment opportunities and their influence in the family, as the family income is more likely to be produced by male members of the household and ultimately will reduce the influence of women in the political sphere.

So far, the women's movement in politics is still very limited. There is an individual protest which was enough to grab the public's attention, including the mass media. This was the political movement carried out by a female journalist named Wajeha al-Huwaider. Wajeha was a Daily Al-Watan reporter and the Daily Arab News, before the two newspapers were banned. In 2003, Wajeha was arrested for protesting women's rights which prevented her from leaving Saudi Arabia, even though the ban was eventually revoked. In 2011, Wajeha was accused of kidnapping, because she tried to help a woman escape to the Canadian Embassy to escape from her husband. Two years later (2013), Wajeha was detained a year and barred from traveling after being charged with takhbib, which was talking about the sex segregation of power between husband and wife (Quila et al., 2016).

The internal and external socio-political changes affect the Saudi Arabian women in different ways. In the last decade, Saudi Arabia has given many privileges that they never had before. In 2011, Saudi Arabian women were given the right to vote in local elections. In the same year, Saudi Arabian women were given the opportunity to run in a local election and for the Consultative Assembly. However, the chances for Saudi Arabian women in politics have so far still not been encouraging. This is not only related to the religious teachings, but many other factors, including the increased of oil production. The growth of oil production, which 
increases demands on the male employees has negatively affected a salary level of female employees. Women's salaries are lower, and there is an increase in non-income women. This has led to a lower participation of the female employees. The lower participation of women in the power as laborers, causes the low political influence of women. Thus, the increase in oil production is aimed at reducing the political influence of women in Saudi Arabia (Ross, 2008).

\section{THE DYNAMICS OF SAUDI ARABIAN WOMEN'S SOCIO- POLITICAL MOVEMENTS}

In general, the socio-political movement in Saudi Arabia contains various content issues. This is because the actors of social and political movements are relatively diverse. The sociopolitical movement is not limited to the religious defenders who criticize the government, but also other groups, including liberal secular groups that tend to object existence of the monarchy. Within the arena of socio-political movements in Saudi Arabia, there are social political movements carried out by women (ADHRB, 2017).

The direction of the women's social political movement in Saudi Arabia (Kingdom of Saudi Arabia / KSA) is how they find the voice of the majority of women in that country, which is majority silent. However, the biological differences in sex continue to be built into the cultural differences, and ultimately lead to the differences in social and political rights (Butler, 2011: 379). Like in other countries, the feminism movement in Saudi Arabia is a movement that fights for men and women to have equal rights politically, economically and socially. Most feminist movements in Saudi Arabia support the idea that there are indeed the biological differences between men and women, but it can be interpreted positively. For example, women are better, healthier and softer than men, and have a mentality that leads to these biological and physiological characteristics. Therefore, according to the assumption of the women's movement, if women rule the world, there will be no war. The radical feminism in Saudi Arabia is a breeding ground for many ideas arising from the modern feminism (MacKinnon, 1982: 543).

Even though there are a number of obstacles, more and more women rights activists in Saudi Arabia are demanding an end to discriminatory law practices. For example, their protest against the driving ban, which has recently become more prevalent compared to the previous periods (al-Sharif, 2012). According to Manal al-Sharif (at Heath 2014, 7) who had led a campaign to end the driving ban, "I believe if women want to change their reality, it will change. But if women keep silent, I don't think anything will change. The rights have never been granted, but they may be taken "(Tonnessen, 2016: 18).

Obviously, the women's protest is not new to Saudi Arabia. Manal al-Sharif's protest was not the first in this country. Dozens of brave Saudi Arabian citizens have bluntly laid the foundation for Al-Sharif and Women Drive 28 years ago. The Saudi Arabian women began filing petitions calling for the government's ban on driving, namely petitions in 2006, 2011 and 2013. All of these petitions were rejected by the Ministry of Internal Affairs and Rural Affairs of Saudi Arabia (Tonnessen, 2016: 19). In 2011, Manal al-Sharif was arrested for campaigning on the women's rights to drive in the public that sphered wildly. In addition, she was also arrested on the grounds that she had helped fellow woman travel alone without their guardian. Traveling alone for the Saudi Arabian women is strictly prohibited. Manal's campaign in 2011 actually had the support of 12,000 people on the Facebook page, but it was still rejected by the kingdom. 
Meanwhile, the possibility of organizing a large-scale demonstration is not possible because the unavailability of facilities in Saudi Arabia becomes a barrier for the Saudi Arabian women. Despite this hundreds, even thousands of women protested demonstratively and were a bit "brutal", because they had no other choice in channeling their aspirations. As a result of the protest movement, not a few women were suspended from their jobs, imprisoned and baned from carrying out more demonstrations (Al Nafjan, 2015). Some activists were even threatened with terrorism charges, because they were considered to have incited the public. Because of its uniqueness, the protest over the ban on driving for women in Saudi Arabia has echoed throughout the world. The campaign was able to attract the attention of international media, until a number of women activists from various countries helped press the government of Saudi Arabia despite not bringing any results (Tonnessen, 2016: 19).

Not only was hindered by the government, the women's rights activists also received the great opposition from the religious lobby. For example in 2012, Ulama Sheikh Adnan Bahareth stated that raising the issue of prohibition on driving would put all parties more than the "burden" on women, because a woman (not her husband or driver) "must go to the market". For themselves, the women must obtain the food, and escort the children to and from school." (Heath 2014, 10). In fact, according to him, women in the common way will control the men, because men must complete the task, not the women. The Saudi Arabian women often described as "spoiled" and have special privileges in the "trusteeship system" (men serving women). Men bring home the paychecks to give to women, and if women choose to work they can spend their salaries on shopping. Thus, it is the mahram as a woman's protector to drive her or give her a driver when she wants to go shopping or go to work. There is a strong class dimension for this display, because it does not take into account the lower class's considerations, including the working immigrants, whose homes depend on the two incomes, but they do not have the means to buy a car. According to the women's rights activist, the Saudi Arabian women are considered weak, no matter how high their status is, even those who are 'spoiled' among them, because they have no law to protect them. "(Tonnessen, 2016: 19).

The recent women's emancipation campaign (2012) received a strong challenge from Saudi sheikhs. The White Ribbon campaign began in Saudi Arabia by two community leaders (Abdullah al-Alami and Samar Fatany). This included speaking out against the child marriages and sexual harassment at work. Sheikh Nasser al-Omar attacked the campaign. Sheikh is the most influential writer in attacking the campaign. In a videotape circulating on YouTube, Sheikh instructed all Muslims to refuse it and he referred to the initiator as a supporter of immorality" (Al Nafjan 2013).

Women's rights activists not only face the resistances from politicians and religious leaders, but also those from other women. It is important to note that for every petition written by women, the human rights activists for debating these rights, there are other women who oppose it. Responding to Huweidar's campaign to abolish the mahram system, "Treating Us Like Adults - Or We Leave the Country," a group of Saudi Arabian women, headed by Saudi Princess Jawaher bint Jalawi, launched a resistance called "My trusteeship system knows what's best for me." This campaign argued that the driving ban is in accordance with the male trusteeship system, and the importance of dignity for the Saudi Arabian women. The campaign organizer aimed at collecting signatures from 1,000 Saudi Arabian women on a petition to be sent to the Saudi King, Abdullah bin Abd Al-Aziz. The petition was strongly opposed to demands to abolish the male trusteeship, along with "all other calls by liberals which would lead to the principle of Islamic westernization" (WLUML 2009).

The Saudi Arabian women's rights activists have been challenged from various parties, including the state, the religious lobbying, and the counterpart campaign of women who have 
the opposite and more conservative views. Thus, not all Saudi Arabian women fall into the category of those who protest the Saudi state's view of proper gender regulation. Le Renard $(2013,2014)$ warned that while women violate the Saudi state's gender norms in daily life, it does not mean that they want to change the whole system. But as the results of this study showed that more and more women's rights activists who actively challenge the male trusteeship system, this makes a variety of clever maneuvers in politics that hinder the environment with strong religious lobbying. Social media has been using for the opposing rules and decisions such as driving restrictions, by starting campaigns on it, and the incorporating the Saudi Arabian women's rights into the international agenda. These social media put pressure on the king slowly, but steadily (Tonnessen, 2016: 19). Twitter is a social media platform that is most widely used by the Saudi Arabian women to issue their complaints.

A study conducted by Khamsi \& Khielfe (2017) toward 130 respondents consisting of managers and leaders in private companies and government offices in Saudi Arabia showed a factor that drives the feminism movement in Saudi Arabia. The seven factors that most make the women's movement react if there is the latest government policy related to women and the substance of the policy is less / not pro-emancipation of women. The second factor is a social network that carries certain issues that are considered important for the benefit of women's emancipation. The third factor is the women's development plan which is the motive for women's participation. The fourth factor is the issues of international organizations and science conferences related to the position and conditions of women in Saudi Arabia. The fifth factor is the tendency that occurs in the communities of Saudi Arabia. The sixth factor is what is needed by the Saudi Arabian community, especially the women. The seventh factor is what encourages the women's movement must be an element that meets the requirements to become a women's issue.

Of the seven factors that can encourage the rise of the women's movement are the government decisions related to women, especially those that are discriminatory. The government's decision to get the first reaction from the women's movement, given the government's decision is the most certain that will apply in the country and directly concerning the fate of women. In the case of Saudi Arabia, the policy of driving restriction for women became a complicated problem that occurred in the country. This policy is a major factor in encouraging social movements in Saudi Arabia. In addition, the trusteeship policy adopted by the government for Saudi Arabian women is also one of the reasons for women to carry out a movement. The trusteeship system for them is considered to hinder their freedom.

Women's movements in Saudi Arabia face a number of administrative and organizational obstacles. Khamsi \& Khielfe Research (2017) showed the eight obstacles. The biggest administrative and organizational constraints are the male domination in leadership positions within the feminist movement organizations. Women are still considered taboo to lead an organization, even though the organization is a women's organization. This obstacle means that it happens to women internally. Other internal constraints are: the lack of women's participation in the employment policy. The rest of the administrative and organizational constraints stem from external factors, both stemming from the weak government support and private sector towards the women's movement. Another external obstacle is the absence of clear standards for the higher administrative positions, in general the women's employment is limited, the legislations are restrictive and the decision makers who believe in the women's interests. 


\section{CONCLUSION}

The women's socio-political conditions in Saudi Arabia could not be separated from the religious values and very strong traditions. These basic values affect the socio-political development of women in Saudi Arabia. In addition, the social conditions of the Saudi Arabian community are also influenced by the internal factors of Saudi Arabia and regional politics. So far, especially in the research period, there has indeed been an increase in the emancipation of women in social, economic and political activities, however, the tendency towards the women's emancipation run very slowly and occurred in very limited aspects. The socio-political movement of women in Saudi Arabia continues echoing, especially since the discovery of oil in the 1930s, and other events in the region and the world. However, the women's movement is limited to the movement of opinion on social media, or occurs demonstratively but it is sporadic and does not occur massively. This is because there are almost no institutions that formally accommodate the women's movement and there are still a number of obstacles to the women's movement including the resistance from women themselves.

\section{ACKNOWLEDGEMENT}

This research based on grant scheme of PITTA (Publikasi International Terindeks untuk Tugas Akhir) or also known as Indexed International Publications for Final Projects toward Universitas Indonesia students. Thank you to Muhammad Lutfhi and Muhamad Syauqillah as my advisors.

\section{REFERENCES}

[1]. Alhareth, Y.A.; Yasra A.A.; \& Ibtisam A.D. (2015). Review of Women and Society in Saudi Arabia. American Journal of Educational Research, 3(2), 121-125.

[2]. Al Nafjan, E. (2011).'The Saudi 'Study' that Finds All Women Drivers on the Road to Immorality," 6/11/2011.1. Downloaded from

[3]. http://www.guardian.co.uk/commentisfree/2011/dec/06/saudi-study-womwn-drivers.

[4]. (2012, July 31). The Olympic Triumph of Saudi Arabian Women. The Guardian. Downloaded from

[5]. http://www.theguardian.com/commentsfree/2012/jul/31/olumpic-triumph-saudiarabian-women.

[6]. Al-Sharif (2012). "Driving My Own Destiny," The Virginia Quarterly Review, 88 (4), 96-101, downloaded from

[7]. http://search.proquest.com/docview/1170961588?accountid-10382.

[8]. Americans for Democracy of Human Rights in Bahrain (ADHRB). (2017). Roads to Reform: The Enduring Work of the Saudi Association for Civil and Political Rights. Washington DC: ADHRB, www.adhrb.org.

[9].

4: Media Censorship. Washington: ADHRB. "Mapping the Saudi State, Chapter

[10]. Butler, K.C.; malaikah, S.J. (1992). Efficiency and inefficiency in thinly traded stock markets: Kuwait and saudi Arabia. Journal of Banking and Finance, 197-210.

[11]. Etheredge, L. S. (2011). Middle East Region in Transition Saudi Arabia and Yemen (1st ed.). New York, Amerika: Britannica Educational Pub. 
[12]. Fyfe, C.F. (2013). A Comparison of Women's Rights in the United Arab Emirates and Saudi Arabia referenced against the United Nations Human Rights Legislation and Selected United Nation's Millenium Development Goals. A dissertation submitted to Auckland University of Technology in partial fullfilment of the degree of Master of Arts (Social Sciences). Downloaded on September 21, 2017 at 16.12 WIB from

[13]. aut.researchgateway.ac.nz/bitstream/handle/10292/7865/FyfeC.pdf?sequence=3

[14]. Heath, R. (2012). "Women's Access to the Labour Market Opportunities, Control of Household Resources, and Domestic Violence.” Policy Research Working Paper 6149. World Bank, Washington, DC. http://ecpn.worldbank.org/external/default/main?pagePK=64165259\&entityID=000158 349_20120726090130

[15]. Irawan, Meilia. (2014). Transformasi Kebijakan Pemerintah Arab Saudi Sejak Tahun 2005: Kontribusi Perempuan di Ranah Sosial dan Politik (The Policy Transformation of Saudi Arabia Government Since 2005: Women Contribution on Social and Political Issues) (Master's thesis, University of Indonesia, 2014). Depok: Library of University of Indonesia.

[16]. Khamshi, S.S.; Khielfe, S.A.A. (2017). Feminist Movement Obstacles in Saudi Arabia. Original research paper, 95-101. Downloaded on August 14, 2017 at 14.18 WIB from thescipub.com/pdf/10.3844/jssp.2017.95.101.

[17]. Quilla, A., Bello, J., \& Kim, A. H. (2016). Women's Rights Organizations in Saudi Arabia and France [Article of the Academies a living and learning community].

[18]. Rajkhan, S.F. (2014). Women in Saudi Arabila Status, Rights, and Limitations. A paper submitted to the facculty of the University of Washinghton Bothell in candidacy for the degree of Master of Arts in Poloicy Studies, University. Downloaded on Augus 14, 2017 at 14.18 WIB from

[19]. https://digital.lib.washington.edu/researchworks/.../Rajkhan\%20-\%20Capstone.pdf

[20]. Renard, A.L. (2017). Personal Development and the 'Rights of Woman": Women's Appropriation of Religion in Saudi Arabia. Downloaded on August 11, 2017 at 12.09 WIB from http://www.sciencespo.fr/ceri.

[21]. (2014). A Society of Young Women: Opportunities of Place, Power, and Reform in Saudi Arabia. Redwood City: Standford University Press.

[22]. Ross, M.L (2008).Oil, Islam, and Women. American Political Science Review, 102: 107-123.

[23]. Sanauddin, N. (2013). A Most Masculine State: Gender, Politics, and Religion in Saudi Arabia. The Kelvingrove Review, Issue 12, Downloaded on September 09, 2017 at 17.06 WIB from https://www.gla.ac.uk/media/media_298317_en.pdf --> look Rashed, M.A.

[24]. Singh, R. (2010). Social Movements, Old and News: A Post-Modernist Critique. Gerakan Sosial Baru (New Social Movement). Darmawan, E.P (2010). First Publishing. Yogyakarta: Resist Book.

[25]. Tonessen, L. (2016) Women's Activism in Saudi Arabia: Male Guardianship and Sexual Violence, 1- 25. Downloaded on August 14, 2017 at 14.13 WIB from https://www.cmi.no/publications/file/5696-womens-activism-in-saudi-arabia.pdf

[26]. WLUML (Women Living Under Muslim Laws). (2013). Child, Early and Forced Marriage: A Multi-Country Study. Report, a sumbission to the UNI Office of the High Commissioner on Human Rights (OHCR)

[27]. "Saudi Arabia" https://www.hrw.org/reports/1992/WR92/MEW2-02.htm accessed on October 04, 2017 at 15:08 wib. 
[28]. "Saudi Arabia: Activists Convicted for Answering Call for Help" https://www.hrw.org/news/2013/06/17/saudi-arabia-activists-convicted-answering-callhelp accessed on October 04, 2017 at 16:08 wib

[29]. "Saudi Arabia: Activists Convicted for Answering Call for Help" https://www.hrw.org/news/2013/06/17/saudi-arabia-activists-convicted-answering-callhelp accessed on October 04, 2017 at pukul 17:05 wib

[30]. "The Global Gender Gap Report 2016" http://reports.weforum.org/global-gender-gapreport-2016/economies/\#economy=SAU accessed on 04 Oktober 2017 at 13:58 wib.

[31]. “World Report 2012: Saudi Arabia. (2012, January 22)."https://www.hrw.org/worldreport/2012/country-chapters/saudi-arabia accessed on May 17, 2017 at 11:52 wib.

[32]. Wajeha al-Huwaider "Fighting for Women's Rights in Saudi Arabia" http://www.washingtonpost.com/wpdyn/content/article/2009/08/14/AR2009081401598 .html accessed on October 04, 2017 at 17:08 wib

[33]. “Women's Rights Organizations in Saudi Arabia and France. Downloaded on July 12, 2017 at 11.03 WIB from curca.buffalo.edu/.../pdfs/.../womens-rights-organizations-insaudi-arabia-and-france 